\title{
41. ON POSSIBLE CONTINUATION OF THE HAWAIIAN-EMPEROR CHAIN IN KAMCHATKA
}

\author{
G. P. Avdeiko, Institute of Volcanology, FESC, USSR Academy of Sciences, Petropavlovsk-Kamchatsky, USSR
}

\section{INTRODUCTION}

According to Wilson's (1963a, b) hypothesis, the volcanoes of the Hawaiian-Emperor Chain are formed as the Pacific lithospheric plate moves over a source of magma in the mantle. Morgan $(1971,1972)$ proposed that these "hot spots" resulted from "mantle plumes" that rise vertically from the core/mantle boundary and that are fixed about the deep mantle and rotating globe poles. The age of volcanoes increases with distance away from the recent "hot spot" beneath Kilauea volcano. The Hawaiian-Emperor bend indicates that the direction of motion of the Pacific plate changed about 40 m.y. ago.

Recent data on the ages of the Hawaiian volcanoes agree with this hypothesis, although the increase in age with distance away from Kilauea volcano along the chain appears to be not exactly linear (Dalrymple et al., 1974; Jackson, 1976; Jarrard and Clague, 1977). The Hawaiian-Emperor bend is about 42 m.y. old (Dalrymple and Clague, 1976). The DSDP Leg 55 data and data on fossil ages of sediments from the holes of DSDP Legs 19 and 32 (Creager, Scholl, et al., 1973; Larson, Moberly, et al, 1975) and the radiometric age of mugearite from Suiko Seamount (Saito and Ozima, 1975) give evidence that a tendency of increasing age with distance from the Hawaiian Ridge is valid also for the Emperor Seamount chain. On the basis of the age of sediments, the minimum age of volcanic rocks from the Meiji Guyot, located on the Obrutchev Rise, is $72 \pm 3$ m.y. (Creager, Scholl, et al., 1973).

The Obrutchev Rise, probably representing a continuation of the Emperor Ridge, extends northwestward parallel to the Aleutian deep-sea trench up to its junction with the Kurile-Kamchatka trench, and then on to the Kronotsky Peninsula in Kamchatka (Figure 1). It seems likely that Kronotsky Peninsula is a direct continuation of the Obrutchev Rise, broken by a deep-sea trench. It is probably supported by tectono-magmatic structures of northwestern trend extending in East Kamchatka from Kronotsky Peninsula to the Tumrok Ridge, against the background of structures of northeastern trend general for Kamchatka.

If this assumption is valid, a chain of volcanoes similar to the volcanoes of the Hawaiian-Emperor chain would be expected on a continuation of the Obrutchev Rise in East Kamchatka, and these volcanoes should be older than the Meiji Guyot, i.e., more than 72 m.y. old.

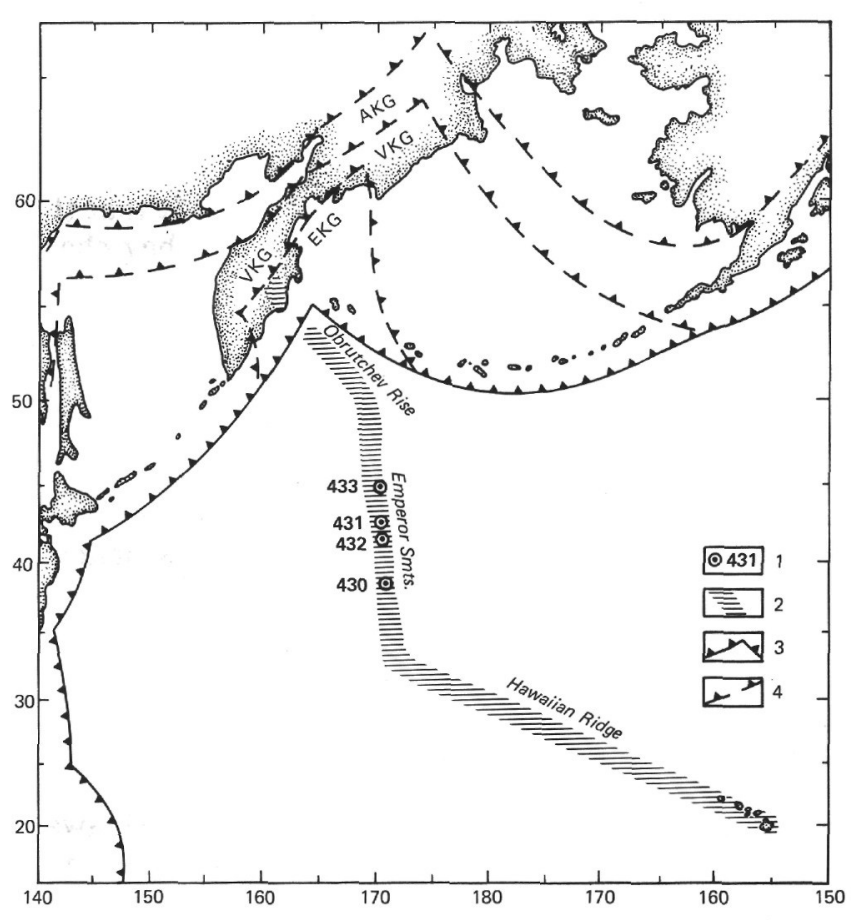

Figure 1. Index map of the North Pacific, showing the location of the Hawaiian-Emperor-Obrutchev chain and former geosynclinal systems. AKG: AnadyrskoKoryak geosyncline; VKG: Vetveisko-Kamchatka geosyncline; EKG: East Kamchatka geosyncline. 1: sites drilled on DSDP Leg 55; 2: island and seamount volcanic chain; 3: modern subduction zone; 4: former subduction zone.

Judging from Morgan's reconstructions (this volume), ${ }^{1}$ a former rift zone (Pacific-Kula lithospheric plate boundary) should be roughly at the latitude of Kronotsky Peninsula. A precise position of this boundary, subducted now beneath Kamchatka and the Aleutian Islands, is unknown. This is followed by the fact that the age of volcanoes may not increase but rather may decrease northwestward.

\section{GEOLOGICAL FEATURES OF KAMCHATKA}

Three major tectonic belts, corresponding to three geosynclinal systems of different ages, may be distinguished in Kamchatka (Avdeiko, 1971). The history of

\footnotetext{
${ }^{1}$ Morgan's paper not submitted in time for publication, but the reconstruction is shown in Figure 10 of Jackson et al. (this volume).
} 
their development was described earlier in detail (Avdeiko et al., 1974; Avdeiko, 1977). Now we shall consider very briefly the principal peculiarities of structure and development of Kamchatka which suggest that the volcanoes of the Hawaiian-Emperor-Obrutchev chain have a common origin and were formed by motion of the Pacific plate over the Hawaiian "hot spot," and that a continuation of this chain may be deduced in Kamchatka.

Boundaries between geosynclinal systems of different ages, representing the ancient zones of subduction, are shown in Figure 1. Rocks of volcanic-siliceous formations, along with spilite-keratophyric associations, mark the early stages of development of these geosynclines. Their ages decrease discretely toward the Pacific Ocean. This regular discrete rejuvenation is also characteristic of the ensuing formations. Correlation of formation in three geosynclinal belts of Kamchatka is presented in Figure 2.

It is of interest to note that the geosynclinal stage of development of East Kamchatka started about 40 m.y. ago, which coincides roughly with the age of the Hawaiian-Emperor bend, i.e., it corresponds to a change in the direction of motion of the Pacific plate. The geosynclinal stage of development of the Vetveisko-Kamchatka tectonic belt began about $80 \mathrm{~m}$.y. ago-that is, close in time to the supposed change in direction of motion of that Pacific plate, which was fixed by the Emperor-Obrutchev bend (see Figure 1). The coincidence may be more complete because the minimum age determined on the basis of sediments overlying volcanic rocks (Creager, Scholl, et al., 1973) for the Meiji Guyot is $72 \mathrm{~m} . \mathrm{y}$. An interval between the end of volcanic activity under terrestrial conditions and the beginning of marine sedimentation can be several million years.

The geosynclinal belt of volcanic rocks in East Kamchatka, whose age ranges from 25 to 40 m.y., extends in a northeastern direction, whereas in the Tumrok Ridge and Kronotsky Peninsula, Upper Cretaceous volcanic rocks occur whose age is 85 to $90 \mathrm{~m}$.y. (Erlich et al., 1971). The lowermost part of the Upper Cretaceous volcanic-sedimentary succession in the Tumrok Ridge, according to Shantser's (1966) data is essentially volcanic. Ultrabasic subvolcanic bodies, lava of picritebasalts and coarse-fragmented tuffs occur at its base. They are overlain by basalts, often pillow basalts intercalated with rare tuff. The thickness of the effusive portion is about 1600 meters. The overlying tuff-siliceous sequence $(600 \mathrm{~m})$ is marked by silicified vitroclastic tuffs intercalated with more coarse-grained tuffs and thin andesite-basaltic porphyrites. This succession resembles the structure of oceanic crust where a tuff-siliceous sequence, pillow basalts, and ultrabasic subvolcanic bodies, along with lava flows of picrite-basalts, correspond to the first layer, second layer, and transition zone between the second and third layers of the oceanic crust, respectively. Erlich et al. (1971) described a stock located in the same succession at the junction of the Tumrok and Kumroch ridges in the source of the Pravy Tolbachik River. This stock, $2.5 \mathrm{~km}$ in diameter, is composed of gabbro-syenites and teschenites in the

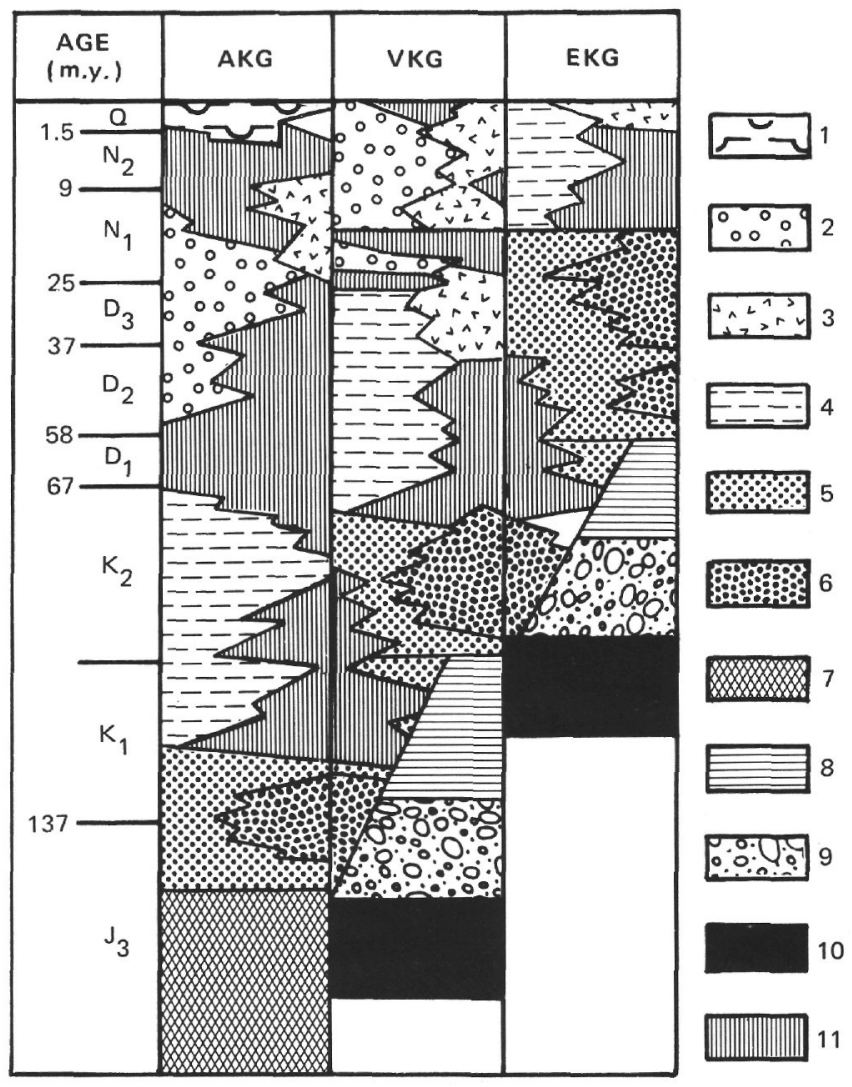

Figure 2. Correlation of formation complexes of the Kamchatka geosynclines (after Avdeiko, 1977). The location of geosynclines is shown in Figure 1. AKG: Anadyrsko-Koryak geocyncline; VKG: VetveiskoKamchatka geosyncline; EKG: East Kamchatka geosyncline. (1) Subplatform formation complexes, (2) orogenic molasse complexes, (3) island arc volcanic complexes, (4) late geosynclinal terrigenous complexes (usually flysch), (5) early geosynclinal terrigenous complexes, (6) early geosynclinal volcanic-siliceous complexes. Basement complexes of geosynclines: (7) heterogeneous basement complex; first (8); second (9); and third (10) layers of the oceanic crust; (11) stratigraphic hiatus.

center and pyroxenites and peridotites in the periphery. A series of conic dikes connected with and dipping toward this stock is composed of meimechites and serpentinites.

A volcanic-sedimentary sequence lies periclinally relative to this stock. Erlich et al. (1971) consider this stock to be a volcanic vent. The sequence is composed of agglomerate tuffs, basalts, and picrite-basalts. Analyses of picrite-basalts and tholeiites from the Tumrok Ridge and Hawaiian Islands and Emperor Seamounts are shown in Table 1. Rocks from the Tumrok Ridge have a high abundance of alkalis, in particular $\mathrm{K}_{2} \mathrm{O}$, and low $\mathrm{TiO}_{2}$ contents in comparison with lavas from the Hawaiian Islands. The high abundance of $\mathrm{K}_{2} \mathrm{O}$ can be accounted for by secondary alterations like those in lava 
TABLE 1

Bulk Chemistry of Some Lavas from the Hawaiian Islands, Emperor Seamounts, and Tumrok Ridge

\begin{tabular}{|c|c|c|c|c|c|c|c|c|c|c|c|c|}
\hline & 1 & 2 & 3 & 4 & 5 & 6 & 7 & 8 & 9 & 10 & 11 & 12 \\
\hline $\mathrm{SiO}_{2}$ & 46.41 & 43.48 & 49.19 & 42.96 & 45.16 & 42.60 & 44.60 & 44.84 & 48.08 & 49.36 & 46.81 & 49.15 \\
\hline $\mathrm{TiO}_{2}$ & 1.98 & 1.82 & 2.06 & 1.32 & 1.39 & 0.50 & 0.52 & 0.50 & 0.54 & 2.50 & 0.60 & 0.63 \\
\hline $\mathrm{Al}_{2} \mathrm{O}_{3}$ & 8.53 & 12.94 & 14.64 & 7.60 & 7.99 & 5.73 & 6.00 & 10.36 & 11.11 & 13.94 & 11.55 & 12.13 \\
\hline $\mathrm{Fe}_{2} \mathrm{O}_{3}$ & 2.47 & 8.51 & 9.63 & 1.73 & 1.82 & 4.41 & 4.62 & 5.54 & 5.94 & 3.03 & 4.33 & 4.55 \\
\hline $\mathrm{FeO}$ & 9.52 & 3.91 & 4.42 & 9.37 & 9.85 & 6.92 & 7.25 & 5.54 & 5.94 & 8.53 & 6.19 & 6.50 \\
\hline $\mathrm{MnO}$ & 0.15 & 0.14 & 0.16 & 0.14 & 0.15 & 0.29 & 0.30 & 0.25 & 0.27 & 0.16 & 0.28 & 0.29 \\
\hline $\mathrm{MnO}$ & 20.81 & 12.28 & 13.89 & 23.87 & 25.09 & 26.56 & 27.81 & 12.49 & 13.39 & 8.44 & 10.29 & 10.81 \\
\hline $\mathrm{CaO}$ & 7.38 & 2.59 & 2.93 & 5.12 & 5.38 & 5.34 & 5.59 & 10.81 & 11.59 & 10.30 & 10.33 & 10.85 \\
\hline $\mathrm{Na}_{2} \mathrm{O}$ & 1.58 & 1.90 & 2.15 & 1.66 & 1.75 & 1.24 & 1.30 & 2.47 & 2.65 & 2.13 & 2.94 & 3.09 \\
\hline $\mathrm{K}_{2} \mathrm{O}$ & 0.32 & 0.74 & 0.84 & 1.24 & 1.30 & 1.65 & 1.73 & 0.46 & 0.49 & 0.38 & 1.62 & 1.70 \\
\hline $\mathrm{P}_{2} \mathrm{O}_{5}$ & 0.20 & 0.09 & 0.10 & 0.11 & 0.12 & 0.27 & 0.28 & - & - & 0.26 & 0.29 & 0.30 \\
\hline $\mathrm{H}_{2} \mathrm{O}^{+}$ & & 5.75 & & 3.17 & & 3.54 & & 3.65 & & & 3.13 & \\
\hline $\mathrm{H}_{2} \mathrm{O}^{-}$ & & 5.70 & & 1.70 & & 0.46 & & 2.73 & & & 1.08 & \\
\hline $\mathrm{CO}_{2}$ & & - & & - & & - & & - & & & 0.30 & \\
\hline $\mathrm{SO}_{3}$ & & - & & - & & 0.32 & & - & & & 0.10 & \\
\hline Total & 99.65 & 99.85 & 100.00 & 99.99 & 100.00 & 99.83 & 100.00 & 99.64 & 100.00 & 99.03 & 99.84 & 100.00 \\
\hline
\end{tabular}

Notes: 1 - Average composition of the oceanic type picrite-basalt from Hawaii (Macdonald and Katsura, 1964). 2-5 - The oceanic type picrite-basalt from the Emperor Ridge, Hole 433C, Flow 19b. Central Chemical Laboratory, Institute of Volcanology, USSR Academy of Sciences (analyst: G. Lets). 2 - Flow top, Sample 433C-23-2, 2-17 cm. 3 - Same without $\mathrm{H}_{2}$ O. 4 - Flow bottom, Sample 433C-24-7, 141-144 cm. 5 - Same without $\mathrm{H}_{2} \mathrm{O}$. 6 - Picrite-basalt from the Tumrok Ridge (Erlich et al., 1971). 7 - Same without $\mathrm{H}_{2} \mathrm{O}$ and $\mathrm{SO}_{3} .8$ - Picrite-Basalt from the Tumrok Ridge (Avdeiko et al., 1974). 9 - Same without $\mathrm{H}_{2} \mathrm{O}$. 10 - Average composition of Hawaiian tholeiite (Macdonald and Katsura, 1964). 11 -

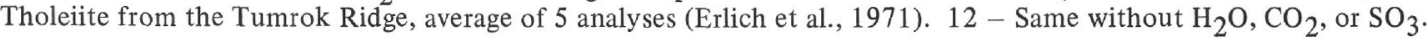

of the Emperor Seamounts. However, the low abundance of $\mathrm{TiO}_{2}$ makes us doubt the reasoning of their comparison with lavas from the Hawaiian Islands and Emperor Ridge. It is worthy of note that lavas from the Tumrok Ridge poured out under submarine conditions, probably in the initial (submarine) period during a stage of shield edifice building, whereas in the Hawaiian Islands the reliable analogues of this stage are unknown (Macdonald and Abbot, 1970).

A similar succession of Upper Cretaceous effusives with pillow lavas was found also on Kronotsky Peninsula. However, here and in the Tumrok Ridge separate volcanic edifices similar to the Hawaiian shield volcanoes were not found.

\section{DISCUSSION}

The Obrutchev Rise, on the northern end of the Emperor Ridge, seems to be a genetic continuation of the Hawaiian-Emperor chain. It was formed by motion of the Pacific plate over a "hot spot". This is indicated by hawaiitic lavas found at the base of Site 192 on the Meiji Guyot (Creager, Scholl, et al., 1973). The Obrutchev Rise is connected with the Emperor Ridge through a bend (see Figure 1). The Emperor-Obrutchev bend, like the Hawaiian-Emperor bend, fixes a change in the direction of motion of the Pacific plate. Data on the time of the beginning of geosynclines in Kamchatka indirectly point to changes in the direction of motion of the Pacific plate. Just as the Hawaiian-Emperor bend corresponds to the beginning of the East Kamchatka geosyncline, the Emperor-Obrutchev bend corresponds to the beginning of the Vetveisko-Kamchatka geosyncline. In both cases, a change in the direction of plate motion leads to generation of a new geosyncline.
The northwestern direction of motion of the Pacific plate in the Cretaceous period seems to be fixed also by the Mid-Pacific Mountains, joining with the Line Islands and Marshall Islands, which join with the Gilbert Islands.

The Kronotsk-Tumrok transverse zone in East Kamchatka is located on a direct continuation of the Obrutchev Rise. At present, reliable data on their genetic connection are absent. Additional studies are needed to support or disprove such a supposition. It is necessary to:

(1) Reveal individual volcanoes along the line Kronotsky Peninsula-Tumrok Ridge and compare them with the volcanoes of the Hawaiian Islands and Emperor Seamount Ridge.

(2) Determine more precisely the age of volcanic rocks similar to those from the Hawaiian Islands, if such rocks are found.

(3) Determine paleolatitudes of lava outpourings.

(4) Compare a succession of sedimentary rocks overlapping volcanites in the Kronotsk-Tumrok transverse zone and sediments which have been drilled in the Emperor Ridge. This work has been started at the Institute of Volcanology, FESC, USSR Academy of Sciences.

If a supposition that the Kronotsk-Tumrok transverse zone is a genetic continuation of the Obrutchev Rise is confirmed, it will be necessary to search for one other mechanism of plate interaction in the subduction zone. It is likely that the underthrusting of the lithospheric plates is incomplete, owing to high buoyancy of aseismic ridges. This resulted in the formation of arrow-like arc junctions, e.g., the Kuril-Aleutian cusp (Vogt et al., 1976). As it was proposed earlier (Avdeiko, 1971) on the basis of evolution of the Kamchatka geo- 
synclines, a continuation of oceanic structures on margins of continents may be indicative also of overjumping subduction zones (see Figures 1 and 2).

\section{ACKNOWLEDGMENTS}

I thank A. V. Koloskov for comments made on the earlier version of the paper and L. Serkova for the help in translating the paper from Russian into English.

\section{REFERENCES}

Avdeiko, G. P., 1971. Evolution of geosynclines on Kamchatka, Pacific Geology, v. 3, pp. 1-13.

, 1977. Geosynclinal volcanism and ophiolites. In Volcanism and Geodynamics. Moscow (Nauka), pp. 15-27 (in Russian).

Avdeiko, G. P., Vande-Kirkov, Y. V., Dmitrenko, N. K., Maleyev, E. F., Ponomarev, G. P., and Florensky, I. V., 1974. Volcanic-Siliceous Formations in Kamchatka. Novosibirsk (Nauka), 116 pp. (in Russian).

Creager, J. S., Scholl, D. V., et al., 1973. Initial Reports of the Deep Sea Drilling Project, v. 19: Washington (U. S. Government Printing Office).

Dalrymple, G. B. and Clague, D. A., 1976. Age of the Hawaiian-Emperor bend, Earth Planet. Sci. Lett., v. 31, pp. 313-329.

Dalrymple, G. B., Lanphere, M. A., and Jackson, E. D., 1974. Contributions to the petrography and geochronology of volcanic rocks from the leeward Hawaiian Islands, Geol. Soc. Amer. Bull., v. 85, pp. 727-738.

Erlich, E. N., Shantser, A. E., and Kutyev, F. S., 1971. Meimechites from East Kamchatka, Izv. AN SSSR, ser. geol., No. 2, pp. 3-9 (in Russian).

Jackson, E. D., 1976. Linear volcanic chains on the Pacific plate. In Sutton, G. H., Maghnani, M. H., and Moberly,
R. (Ed.), Geophysics of the Pacific Basin and its Margin: Amer. Geophys. Un. Mono. 19, pp. 319-335.

Jarrard, R. D. and Clague, D. A., 1977. Implications of Pacific island and seamount ages for the origin of volcanic chains, Rev. Geophys. and Space Physics, v. 15, No. 1, pp. $57-76$.

Larson, R. L., Moberly, R., et al., 1975. Initial Reports of the Deep Sea Drilling Project., v. 32: Washington (U. S. Government Printing Office).

Macdonald, G. A. and Abbott, A. T., 1970. Volcanoes in the Sea. The Geology of Hawaii: Honolulu (University of Hawaii Press), 441 pp.

Macdonald, G. A. and Katsura, T., 1964. Chemical composition of Hawaiian lavas, Jour. Petrology, v. 5 (1), pp. 82-133.

Morgan, W. J., 1971. Convection plumes in the lower mantle, Nature, v. 230, pp. 42-43. 1972. Deep mantle convection plumes and plate motions, Amer. Assoc. Petrol. Geol. Bull., v. 56 (2), pp. 203-213.

Saito, K., and Ozima, M., 1975. ${ }^{40} \mathrm{Ar}-{ }^{39} \mathrm{Ar}$ isochron age of a mugearite dredged from Suiko Seamount in the Emperor chain, Rock Mag. and Paleogeophys., v. 3, pp. 81-84.

Shantser, A. E., 1966. On volcanic and terrigenous formations of Cretaceous (?) age in Eastern Kamchatka Ridge. In Stratigraphy of Kamchatka Volcanic Formations: Moscow (Nauka), pp. 10-14 (in Russian).

Vogt, P. R., Lowrie, A., Bracey, D. R., and Hey, R. N., 1976. Subduction of aseismic oceanic ridges: Effects on shape, seismicity and other characteristics of consuming plate boundaries, Geol. Soc. Amer. Spec. Paper 172, 59 pp.

Wilson, J. T., 1963a. A possible origin of the Hawaiian Islands, Canadian J. Physics, v. 41, pp. 863-870. $1963 \mathrm{~b}$. Evidence from islands on the spreading of the ocean floor, Nature, v. 197, pp. 536-538. 